\title{
An Introduction by the guest co-editors
}

\author{
Montse ABAD CASTELOS and Laura CARBALLO PIÑEIRO*
}

The Spanish Association of Professors of International Law and International Relations (AEPDIRI) is the beneficiary of a Jean Monnet project on the pressures experienced by EU law in a globalized world, pressures that become apparent in the conflicting trends towards universalism on the one hand and states' legal fragmentation on the other hand. Overall objective of the project is the promotion of research on EU policies from the perspective of the Association's research areas - public international law, private international law and international relations - with a view to enhancing EU values beyond its borders.

It is in the framework of this Jean Monnet project that AEPDIRI jointly with the Universities of A Coruña, Santiago de Compostela and Vigo organized an international Conference held on June I8 and 19, 2015 in Vigo (Spain), on "the Extraterritorial Application of EU Law". The AEPDIRI invited outstanding researchers in their fields to this conference but, in particular and in order to draw the attention of young researchers to this research, it made a call for papers.

Many young researchers but also experienced researchers responded from all over the world. All papers were anonymously submitted to the Scientific Committee set up for this purpose, and only those that were selected by this Committee in accordance with scientific criteria were invited to the Conference. The panels were the following ones: EU, Values and Human Rights; The Extraterritorial Application of EU Law: Trade, Societies and Contracts; The Fight against Corruption from an International Law Perspective; The Extraterritorial Application of Intellectual Property Rights; The Extraterritorial Application of Data Protection Legislation; Extraterritorial Application of EU Competition Law; The Extraterritorial Application of Environmental Law; and Fishing Industries Confronting Changes in the Maritime Legal Scenario.

The presentations were of the highest competence and scientific quality, providing an excellent level of expertise. In line with the European Union's and AEPDIRI's interest in promoting their activities, the decision was taken of publishing the papers. Against this background, SYbIL seemed to be the best choice given its international spreading as an online journal written in English. For those who presented their papers at the Vigo Conference have the appeal of being a journal that publish on a blind-peer-review-process basis and for both, the EU and the AEPDIRI, have the advantage of making highly visible their commitment to science.

\footnotetext{
Carlos III University of Madrid / Santiago de Compostela University.
} 
The abovementioned panels show that a variety of topics were discussed at the Vigo Conference. While the leitmotiv was that all of them dealt with the extraterritorial application of EU law, the outcome was cutting-edge research and the publication of this research in the SYbIL is in line with its goal of providing an annual report on developments in international law. The fact that the Vigo Conference was organized by the AEPDIRI was another reason to sustain the publication of the aforementioned papers in SYbIL. On account of the latter being edited by the former, the spreading of AEPDIRI's scientific activities and their stakeholders' research is in line with SYbIL's objectives as well.

The publication in this Agora has been coordinated by two members of the AEPDIRI Board as guest co-editors, and all papers went through the said blind peer-review process again. Unfortunately, not all participants could finally join the publication as it would have been desirable. Parallel commitments and other circumstances made it absolutely impossible for many of them to meet the deadline to which every yearbook must strictly stick. This has resulted in the distribution in panels of the Vigo Conference not being kept in this Agora. Nevertheless, the variety of papers finally published is an excellent representation of those panels.

This Agora is thus the outcome of a very long process in which many professors and researchers have taken part, from the organizing of the conference to the blind peer-review process. The coeditors would like to thank all of them, in particular the members of the conference's scientific committee and reviewers for their commitment to science and generosity in terms of time and comments. A special thank is due to the Organising Committee of the Vigo Conference, Professors Enrique J. Martínez Pérez, Miguel-Ángel Michinel Álvarez, Belén Sánchez Ramos and Marta Sobrido Prieto to the extent that all this would have not been possible without their constant support and joy. The same applies to the SYbIL's Editorial Board and in particular its director, Professor Mariano Aznar, as they did not doubt in opening the doors of this excellent yearbook to this project. The lively debate along with the splendid academic and non-academic environment during the conference days will remain as part of our best memories and we are very grateful to all participants in the Vigo Conference for that. The AEPDIRI with its critical mass made this possible and it only remains to encourage the readers to join the discussion. 